\title{
DAI-ME AGÔ (LICENÇA) PARA FALAR DE SABERES TRADICIONAIS DE MATRIZ AFRICANA NO ENSINO DE QUÍMICA
}

\author{
Anna M. C. Benite ${ }^{\mathrm{a}, *,(\mathbb{D}, \text { Gustavo A. A. Faustino }}{ }^{\mathrm{a}}$, Juvan P. Silva ${ }^{\mathrm{a}}$ e Claudio R. M. Benite ${ }^{\mathrm{a}}$ \\ anstituto de Química, Universidade Federal de Goiás - UFG, Campus II Samambaia, 74690-900 Goiânia-GO, Brasil
}

Recebido em 26/12/2018; aceito em 27/02/2019; publicado na web em 01/04/2019

\begin{abstract}
GIVE ME “AGÔ" TO TALK ABOUT TRADITIONAL AFRICAN MATRIX KNOWLEDGE IN CHEMISTRY TEACHING. This paper presents the results of a participant research. We represent the science class-room as conditioned by the heterogeneity of the identities constituting it from positions that are defined and legitimized by our social structure. We present a pedagogical intervention (PI) entitled "Traditional knowledge of African-matrix peoples and communities". The PI was audio and video recorded and analyzed using Discourse Analysis. Our results show that the religiosity of Brazilian African-matrix is nowadays a resignification of the cults of various ethnic groups in the African continent, in this sense, the plants and leaves were incorporated to people's everyday life. Plants perform a sacral role of symbolic value and a functional role through its chemical components. We understand scientific knowledge is not traditional knowledge, but it relates to it. Our results show how it is possible to bring these topics to the Chemistry class-room. To establish a dialogue among these various forms of interacting with the world is necessary to break up with the epistemicide reaching our classrooms.
\end{abstract}

Keywords: traditional peoples and communities; African matrix; medicinal plants; chemistry teaching.

\section{À GUISA DE INTRODUÇÃO}

Frutos de trabalho, de concordância com pactos internacionais nos quais o Estado brasileiro se compromete com as implementações de políticas de combate ao racismo, a declaração de Durban, ${ }^{2}$ por exemplo, e principalmente pela luta das diferentes representações do movimento negro organizado, em 09 de janeiro de 2003 é assinada pelo então presidente da República Luiz Inácio Lula da Silva a lei $10.639 / 03^{3}$ que inclui a obrigatoriedade de estudos sobre a cultura afro-brasileira e africana em todos os níveis de ensino alterando a lei maior da educação, a Lei No 9.394/1996 - LDB. ${ }^{4}$

Para orientar professores/as, pesquisadores/as e outros entes ligados aos sistemas de ensino, em 2004 o governo brasileiro publica o parecer CNE/CP 003/2004 que normatiza as Diretrizes Curriculares Nacionais (DCN) para a Educação das Relações Étnico-Raciais (ERER) e para o Ensino de História e Cultura Afro-brasileira e Africana, cujo dever é "fazer justiça à história e cultura provenientes do continente africano, em contínuo desenvolvimento e transformação na diáspora negra". ${ }^{5}$ Isso significa recontar a história do/a negro/a de uma forma positiva colocando-o/a como protagonista no desenvolvimento cultural, social, tecnológico e político do país.

Ressalta-se ainda que o parecer CNE/CP 003/2004 determina o papel de cada ator/a na recontagem dessa nova história do/a negro/a, quais sejam os estabelecimentos de ensino, seus/suas mantenedores/as, administradores/as, professores/as, famílias dos/ as estudantes, os/as próprios/as estudantes e, por fim, a todos/as os/as cidadãos/as comprometidos com a educação dos/as brasileiros/as e que estejam comprometidos com a formação para a cidadania responsável pela construção de uma sociedade justa e democrática. ${ }^{5}$

O papel das Instituições de Ensino Superior (IES) é contemplado no $\S 1^{\circ}$ que diz que essas deverão incluir em seus conteúdos "disciplinas e atividades curriculares dos cursos que ministram a ERER" (p.1) e prever que o cumprimento dessas DCN por parte das IES que oferecem cursos de graduação presencial ou a distância

\footnotetext{
*e-mail: anna@ufg.br
}

seja "considerado na avaliação das condições de funcionamento do estabelecimento" (p.1). ${ }^{5}$

Suas principais ações estão explicitadas no Plano Nacional de Implementação das DCN para a ERER e para ensino de História e Cultura Afro-brasileira e Africana. ${ }^{6}$ Dentre essas estão: incluir conteúdos e disciplinas curriculares relacionados à ERER nos cursos de graduação; dedicar especial atenção aos cursos de licenciatura e formação de professores/as e; desenvolver nos/as futuros/as professores/ as habilidades e atitudes que os permitam contribuir para a ERER.

Dentre os cursos de formação inicial e continuada de professores/as estão os cursos de Matemática e Ciências que incluem as disciplinas de Matemática, Física, Biologia e Química. No entanto, nos documentos legais que orientam o estudo de ERER não está explícito o papel desses cursos e de seus/suas professores/as. Nas orientações e ações para a ERER publicado pelo MEC em 2006, no que tange ao campo das Ciências da Natureza e suas Tecnologias o papel da Química é citado apenas em trabalho por projeto e que "esse pode incluir diferentes disciplinas: Física, Química, Matemática e mesmo História, Sociologia e Filosofia" (p.196). ${ }^{7}$

Dessa maneira alguns/algumas educadores/as, pesquisadores/ as e formadores/as de professores/as de ensino de Ciências, muitos destes/as também ativistas do movimento negro, começam a se questionar como se posicionar diante dessa situação. Segundo Verrangia, ${ }^{8}$ "por que ensinar história e cultura afro-brasileira e africana no ensino de Ciências? Porque é obrigatório? Como fazer isso se, de forma geral, os/as docentes não são preparados/as para tal ação?” (p. 2). Assim, passamos por apresentar quais temas os/as pesquisadores/as da área de ensino de Química têm trazido para a discussão desde a publicação da lei 10.639/03, do parecer CNE/CP 3/2004 e da resolução CNE/CP 1/2004. ${ }^{9}$

No ensino de Química o debate se inicia com a publicação, em 2007, de dois artigos ${ }^{10,11}$ nos quais o autor faz alguns apontamentos de como o ensino de Ciências/Química pode contribuir para uma educação antirracista. Pesquisas de como os/as professores/as de Ciências e Matemática veem a aplicação da Lei 10.639/03, ${ }^{12-14}$ bem como quais entendimentos que os/as alunos/as têm a respeito da aplicação das DCN para a ERER foram realizadas. ${ }^{15-17}$ Objetos virtuais 
de aprendizagens (OVA) $)^{18-20}$ e os livros didáticos ${ }^{21}$ foram abordados em pesquisas como facilitadores ou não da aplicação das ERER no ensino de Química.

Temas transdisciplinares, como Direitos Humanos, ${ }^{22}$ a Arte, ${ }^{23}$ Música/Poesia ${ }^{24,25}$ e as interdisciplinaridades, como a anemia falciforme ${ }^{26} \mathrm{o}$ átomo e o genocídio,${ }^{27}$ desigualdades de raça e gênero e a produção científica, ${ }^{28}$ protetores solares e a mídia, ${ }^{29}$ produções científicas do antigo Egito, ${ }^{30}$ também fizeram parte do leque de assuntos pesquisados como possibilidade de implementação da lei 10.639/03 no ensino de Química. Ciclos econômicos do Brasil Colônia, como o do café, ${ }^{31,32}$ cana-de-açúcar ${ }^{33}$ e mineração, ${ }^{34-36}$ assim como debates como biocombustíveis ${ }^{37}$ e a vitamina $C,{ }^{38}$ também foram objetos de pesquisas na área.

A extração de platina ${ }^{39}$ na África do Sul e a exploração do Coltan ${ }^{40}$ (mineral formado por Tântalo e Nióbio $)^{41}$ na República Democrática do Congo foram temas utilizados para contextualizar em aulas de Química. O elenco de temas utilizados por pesquisadores/as da área de Ensino de Química, como propostas para uma efetiva implementação da lei 10.639/03, é contemplado na reinvenção do poder no currículo ${ }^{42}$ com discussões sobre a química presente na noz de cola, ${ }^{43}$ no dendê ${ }^{44}$ e nas plantas utilizadas em religiões de matriz africana, sobretudo no Candomblé e Umbanda.

\section{SOBRE OS POVOS E AS COMUNIDADES TRADICIONAIS}

"Ki Ntoo bò Orìsà à è. Portanto, adorarei as minhas origens".

Os Povos e Comunidades Tradicionais de Matriz Africana em todo o território nacional são constituídos por:

[...] quilombolas, ciganos, seringueiros, castanheiros, quebradeiras de coco-de-babaçu, comunidades de fundo de pasto, faxinalenses, pescadores artesanais, marisqueiras, ribeirinhos, varjeiros, caiçaras, praieiros, sertanejos, jangadeiros, açorianos, campeiros, varzanteiros, pantaneiros, caatingueiros (p.1). ${ }^{45}$

Esses são hoje, aproximadamente, cinco milhões de brasileiros/as que ocupam $1 / 4$ do território nacional ${ }^{45}$ e foram reconhecidos em 2007 através do decreto Decreto $6.040 .{ }^{46}$ Este decreto instituiu a Política Nacional de Desenvolvimento Sustentável dos Povos e Comunidades Tradicionais (PNPCT) e os define como:

[...] grupos culturalmente diferenciados e que se reconhecem como tais, que possuem formas próprias de organização social, que ocupam e usam territórios e recursos naturais como condição para sua reprodução cultural, social, religiosa, ancestral e econômica, utilizando conhecimentos, inovações e práticas gerados e transmitidos por tradição (p.1). ${ }^{46}$

Por sua vez, os Povos Tradicionais de Matriz Africana se "reconhecem como unidades de resistência africana no Brasil e se caracterizam pela manutenção de um contínuo civilizatório africano, constituindo territórios próprios marcados pela vivência comunitária" (p.35). ${ }^{47}$ E é a partir do texto "Povos Tradicionais" construído por lideranças do segmento de todo o país e de todas as matrizes, durante a III Conferência Nacional de Igualdade Racial (III CONAPIR), que se definem:

Povos Tradicionais de Matriz Africana: conjunto dos povos africanos para cá transladados, e às suas diversas variações e denominações originárias dos processos históricos diferenciados em cada parte do país, na relação com o meio ambiente e com os povos locais;

Comunidades Tradicionais de Matriz Africana: Territórios ou Casas Tradicionais - constituídos pelos africanos e sua descendência no Brasil, no processo de insurgência e resistência ao escravismo e ao racismo, a partir da cosmovisão e ancestralidade africanas, e da relação desta com as populações locais e com o meio ambiente (p.1). ${ }^{48}$

Os Povos e Comunidades Tradicionais de Matriz Africana constituídos de territórios próprios, incluindo os chamados "terreiros" e "roças", se caracterizam pelo acolhimento e a vivência em comunidade (cooperativismo), ressignificando aqui no Brasil conhecimentos e valores civilizatórios trazidos de África, tais como a oralidade, a corporeidade, a ancestralidade, a circularidade, a musicalidade, a memória, a energia vital (axé) e a religiosidade. ${ }^{49}$ No entanto, esses valores civilizatórios Afro-brasileiros e Africanos são reduzidos, por vezes, a religiosidade e a relação com o sagrado.

Esse reducionismo das práticas tradicionais de matriz africana apenas a "religião", nega a real dimensão histórica e cultural dos territórios negros constituídos no Brasil, e, ainda nos coloca diante de uma armadilha, a do Estado Laico, que na prática ainda está longe de ser real, mas o é quando está em "risco" a hegemonia cultural eurocêntrica no país (p. 1). ${ }^{48}$

Seguindo essa linha do tempo na qual o estado brasileiro tenta integrar e ampliar as ações voltadas aos Povos e Comunidades Tradicionais de Matriz Africana tivemos a promulgação do Decreto 6.040 em 2007, a III Conferência Nacional de Promoção da Igualdade Racial - CONAPIR em 2011, passando pelo lançamento do I Plano Nacional de Desenvolvimento Sustentável dos Povos e Comunidades Tradicionais de Matriz Africana em 2013, ${ }^{50}$ culminando em 09 de maio de 2016 com a instituição do Conselho Nacional dos Povos e Comunidades Tradicionais - CNPCT, integrado ao Ministério do Desenvolvimento Social e Combate à Fome que em seu $\$ 2^{\circ}$ afirma na I competência "[...] vistas a reconhecer, fortalecer e garantir os direitos destes povos e comunidades, inclusive os de natureza territorial, socioambiental, econômica, cultural e seus usos, costumes, conhecimentos tradicionais" (p.1). ${ }^{51}$ Por fim, entre os dias 27 e 30 de maio de 2018 foi realizada a IV CONAPIR com a temática - "O Brasil na década dos afrodescendentes: reconhecimento, justiça, desenvolvimento e igualdade de direitos".

Entendemos aqui ser esse um reconhecimento tardio, pois entre os séculos XVI e XIX mais de sete milhões de homens e mulheres africanos/as foram arrancados/as à força de sua terra mãe para ter aqui, do outro lado do Atlântico Sul, a sua mão de obra especializada escravizada. "Trouxeram para o país mais que sua força de trabalho, trouxeram tecnologias agrícolas e de mineração, suas culturas, saberes, tradições e valores civilizatório" (p.1) (8) $^{48}$ muitas das vezes são reduzidos apenas à religião e ao culto ao sagrado.

Não se entende aqui nenhum demérito em estudar as religiões de matriz africana em todas as suas nuances, pois elas, segundo Ferretti, são consideradas como "foco de resistência cultural e de preservação da identidade étnica" (p.95). ${ }^{52}$ Deste modo, seguem "como sendo os locais de manutenção e preservação da cultura africana" (p.19). ${ }^{53}$ Contudo, historicamente têm sido vistas como cercadas de mistérios e seus ritos não são conhecidos pela grande maioria da população, o que por certo contribui para o processo de intolerância religiosa. ${ }^{53}$

A mistificação da religiosidade de matriz africana as torna vítimas de violações de seus direitos sociais, políticos, econômicos e culturais. ${ }^{54}$ Segundo o dossiê, "a situação dos direitos humanos das mulheres negras no Brasil":

A cada três dias, o Disque Direitos Humanos - Disque 100, recebe uma denúncia de intolerância religiosa. Este serviço telefônico e de internet que tem se dedicado à recepção de denúncia de violação de direitos humanos no Brasil, percebeu um aumento de 273\% nas denúncias no período 2013-2014. 
No ano de 2013, 20\% dos casos denunciados envolveram violência física. Os ataques envolvem também ofensas, perseguições, injurias difamação, chegando até incêndios provocados em templos religiosos (p.35). ${ }^{55}$

Nesse sentido, a mistificação se dá pelo desconhecimento da cultura Africana e Afro-brasileira causando, assim, diversos vilipêndios a esse grupo social. Entender suas religiões e participações no contexto social do Brasil de hoje se faz necessário à compreensão do passado. ${ }^{53}$ Entre as religiões de matriz Africana praticadas em território nacional estão a Umbanda e o Candomblé, sobre as quais se apresentará, neste estudo, uma breve e despretensiosa descrição.

A Umbanda é citada por diversos autores/as como a única religião genuinamente brasileira. No entanto, percebem-se em suas características vários elementos de religiões africanas, do catolicismo e do espiritismo. A mesma surgiu nos subúrbios da cidade do Rio de Janeiro, no início do século passado, com a abertura dos centros espírita kardecistas para os cultos afro-brasileiros e da influência, sobre estes, das ideias do espiritismo e dos valores do mundo branco. ${ }^{56}$

Suas cerimônias podem ser realizadas nos mais diversos locais, em casa, terreiros, praças públicas, em meio à natureza, à beira de um rio ou numa praia. Elas são presididas por um "pai" ou uma "mãe" que são as lideranças que comandam os ritos e são responsáveis por ensinar os seus preceitos aos seus discípulos/as. ${ }^{57}$ Trata-se de uma religião que cultua elementos de personificação ligados a natureza e as suas energias chamados de Orixás. ${ }^{57}$ Exemplos de Orixás encontrados na Umbanda são: Oxalá (ligado à fé), Xangô (ligado à justiça), Iemanjá (ligada à geração), Ogum (ligado à Lei), Oxóssi (ligado ao conhecimento), Oxum (ligado ao amor), Iansã (ligada à direção), Omulú (ligado à estabilidade) e Nanã (ligada à decantação).

A palavra Candomblé é de origem Bantu (do Kimbundu) e vem de uma junção das palavras Kandombe-Mbele que tem o significado de: pequena casa de iniciação dos negros. ${ }^{58}$ Já a religião Candomblé é de origem africana monoteísta e o Deus único para a Nação Ketu é Olorum, para a Nação Bantu é Zambi, para a nação Jeje é Mawu, que são nações independentes na prática diária. ${ }^{59} \mathrm{O}$ seu surgimento no Brasil foi marcado, entre outros fatores, pela necessidade de diferentes grupos negros/as de reelaborarem sua identidade social e religiosa sob as condições adversas da escravidão e, posteriormente, do desamparo social..$^{59}$ Seus rituais são praticados em casas, roças ou terreiros por meio de cânticos, danças, batidas de tambores, oferendas de vegetais, minerais, objetos e, às vezes, o sacro-ofício de alguns animais e podem ser de linhagem matriarcal, patriarcal ou mista. Por conseguinte, as celebrações são dirigidas pelas lideranças religiosas que são nomeadas "babalorixâ" e "iyalorixá"; "Tata Nkisi" e "Mametu Nikisi"; e Doté e Doné, respectivamente, de acordo com as três macro-nações: nação Ketu que cultua os Orixás, Angola que cultua os Inkices e a Jeje que cultua os Voduns.
Os Orixás (nome genérico das divindades Yoruba, intermediários entre Olorum, o Deus supremo e os seres humanos) são os ancestrais, os antepassados simbolicamente divinizados e ligados a natureza, uma recriação Afro-brasileira da religião tradicional Africana reelaborada no Brasil. ${ }^{60}$ Os/as africanos/as e seus descendentes transpuseram fronteiras territoriais e culturais e hoje é um patrimônio de todo povo diaspórico. ${ }^{60}$ Os Orixás não são uma ideia abstrata, eles fazem parte da vida das pessoas ligadas a um terreiro. Por exemplo, se diz nos terreiros que "O Xangô de Obaraym disse que está contente"; "Oxóssi de Mãe Stella deu flores a Oxum de Dona Pinguinho"; "Oxum da Mãe Rosa dançou com muita graça"; a "Yansã de mãe Sofia veio no dia da 'obrigação' de José Félix para Ossanyin e, como sempre dançou muito bonito" (p.43). ${ }^{60}$

Assim, como na Umbanda, no Candomblé, conforme foi dito, cada Orixá está ligado a um elemento da natureza e possui o seu próprio significado. O chamado Panteão dos Orixás do Candomblé, segundo Siqueira, ${ }^{60}$ é liderado por Exu, seguido por Oxalá, Iyemanjá, Xangô, Ogum, Oxum, Logum Edé, Oxóssi, Yansã, Nanã, Omolu ou Obaluayé, Oxumaré, Ossayn, Euá, Obá, Iroko, Ibeji e Erê. Dentre esses, Ossayn é o Orixá das folhas e ao lado de Ifá que tem o poder de prever o futuro, poder este também associado à força das plantas. O conhecimento do nome de cada planta, do poder que lhe é atribuído, bem como sua utilidade e o uso que dela deve ser feito constituem uma das riquezas essenciais do Candomblé. Siqueira afirma que Pierre Verger ${ }^{60}$ designa esse conhecimento sob os termos de "farmacopeia africana".

Assumidos estes pressupostos, passamos a discorrer sobre uma proposta de implementação da lei 10.639/03 considerando, com o devido agô (respeito), a circulação de informações sobre as religiões de matriz Africana. Apresentamos resultados de uma Intervenção Pedagógica (IP) realizada no $1^{\circ}$ semestre de 2015 numa disciplina cujo título é "Ensino de Química, Identidade e Cultura Afro-brasileira" que foi ministrada em um Instituto de Química (IQ) de uma Instituição Federal de Ensino Superior (IFES).

\section{SOBRE AS ESCOLHAS METODOLÓGICAS}

Este trabalho apresenta elementos de uma pesquisa participante (PP). Trata-se, portanto, de uma atividade educativa de investigação e ação social. ${ }^{61}$ Cabe esclarecer que a participação em uma pesquisa, segundo Demo, está para além de pertencer a essa comunidade, mas dar voz a ela, especificamente no trato com o se situar dentro de uma sociedade composta por diferentes etnias. ${ }^{62}$ Esta investigação obedeceu as seguintes etapas (Quadro 1).

Neste caso, assumimos as duas posições, pois representamos os/as professores/as de Ciências que ensinam para a sociedade brasileira que é multicultural e multirracial e, também, os/as membros dessa sociedade, isto é, representa-se a sala de aula de Ciências

Quadro 1. As fases de desenvolvimento da pesquisa participante

Fase 01: Montagem Institucional e Metodológica da PP

Fase 02: Estudo preliminar da região e da população envolvida

Fase 03: Análise crítica dos problemas considerados prioritários e que os/as participantes desejam estudar
Planejamento conjunto por professora formadora (PQ), professor em formação continuada de doutorado (AD), professor em formação continuada de mestrado (AM) e professor em formação inicial (IC) das atividades a serem desenvolvidas na perspectiva do ensino de Química com abordagem em caráter interdisciplinar, baseando-se em aspectos da Lei 10.639/2003.

Discussão da temática de cultura Africana e Afro-brasileira no currículo escolar dos/as futuros/ as profissionais formados/as pela IFES.

Análise da dinâmica discursiva do processo de ensino-aprendizagem dos conteúdos de Química associados ao tema de plantas em religiões de matriz Africana e suas contribuições fitoquímicas discutidos nas aulas utilizando a técnica da análise do discurso (AD) de Bakhtin.

Fase 04: Programação e desenvolvimento de um plano de ação que contribua para a solução dos problemas encontrados
Planejamento conjunto das atividades a serem desenvolvidas e ações pedagógicas dos/as professores/as, em formação inicial e formação continuada, em sala de aula, por meio de produção de material didático e bibliográfico. 
condicionada pela heterogeneidade de sua constituição identitária a partir de posições definidas e legitimadas nessa estrutura social.

Pode-se dizer, nas palavras de Schmidt, que "o termo participante sugere a controversa inserção de um pesquisador formado pela vida sócio-cultural de um próximo ou distante que, por sua vez, é convocado a participar da investigação na qualidade de informante, colaborador ou interlocutor" (p.14).$^{55}$ Os elementos de uma pesquisa participante estão assim demarcados: nós pesquisadores/as e autores/ as deste artigo fazemos o papel do/a pesquisador/a; a comunidade que queremos pesquisar é um Instituto de Química; o problema que temos para ser resolvido nessa comunidade é a não aplicação da lei 10.639/03 em seus cursos de graduação em Química; os/as nossos/ as informantes são os/as alunos/as que vieram cursar uma disciplina baseada na 10.639/03 e no parecer 03/2004 e; a disciplina consolidada, com ementa, com indicação de bibliografia, etc. é o produto de nossa pesquisa que devolvemos para a comunidade.

O corpus empírico desta investigação foi construído na disciplina intitulada "Ensino de Química, Identidade e Cultura Afro-brasileira" de natureza núcleo livre, ou seja, de acesso a qualquer curso e discente da instituição que desde o ano de 2015, numa iniciativa inédita, tem sido oferecido pelo IQ dessa IFES. A disciplina possui uma carga horária de $4 \mathrm{~h}$ /aula semanais perfazendo um total de $64 \mathrm{~h} /$ aulas semestrais e foi construída de modo a contemplar o ensino de Química a partir de matriz cultural não eurocêntrica provocando um deslocamento epistêmico do currículo em ação. O Quadro 2 apresenta a ementa da disciplina.

Quadro 2. Ementa da disciplina Ensino de Química e Cultura Afro-brasileira (grifo nosso)

A arqueologia da África e suas técnicas. Processos de datação. Elementos da diáspora africana no Brasil e o ensino de Química. A química do ferro e o papel do ferreiro Africano nas sociedades Centro-Africanas e no Brasil colônia. A química do dendê e a sua importância nas religiões de matriz Africana e na culinária Afro-brasileira. Abordagem etnobotânica acerca de plantas utilizadas nas religiões de matriz Africana. Produção de diamantes e metais nobres em alguns países do continente Africano e suas implicações nas guerras civis em África.

Foram sujeitos desta investigação (SI) uma professora formadora (PQ), um professor em formação continuada aluno de doutorado (AD), um professor em formação continuada aluno de mestrado (AM) e um professor em formação inicial aluno de iniciação científica (IC), esses quatro membros do Coletivo Negro/a de professores/as, pesquisadores/as e estudantes instalado no IQ da respectiva IFES, e 16 alunos/as de uma disciplina de Núcleo Livre (A1 a A16) dos seguintes cursos: 4 alunos/as das Licenciaturas (Ciências Biológicas, Geografia,
História e Química), e 12 alunos/as do bacharelado: 04 alunos/as das Engenharias (Alimentos, Ambiental, Química e Agronomia), 03 alunos/as da Medicina Veterinária, 01 do Bacharelado em Química, 01 do Bacharelado em Farmácia, 01 da Comunicação/ Jornalismo, 01 da Biblioteconomia e 01 de Sistema da Informação.

Com o objetivo de ensinar uma Química descolonizada, para cada assunto tratado na disciplina existem duas abordagens: uma cultural de matriz Africana e outra conceitual (conhecimento químico), tal como apresentado no Quadro 3. Portanto, ensinar uma Química descolonizada, "[...] significa admitir a força das culturas consideradas negadas e silenciadas nos currículos" (p.102). ${ }^{63}$

Um dos elementos de avaliação desta disciplina se constituiu de apresentação de seminários em forma de mini-aulas dialogadas, nos quais os/as alunos/as teriam que mostrar como fariam as abordagem cultural e conceitual, como mostradas no Quadro 2 e na ementa da disciplina, em uma aula de Ciências/Química na educação básica ou superior, simulando estas aulas com a turma.

As escolhas dos componentes de cada grupo para apresentação dos seminários se deu de forma livre, todavia foi sugerido que ficasse pelo menos um/a aluno/a de Química (licenciatura/bacharelado/ engenharia) ou licenciatura em cada grupo. Os/as alunos/as ficaram livres para trazerem outras referências diferentes das que foram apresentadas no plano de ensino do curso. Dessa maneira, emergiram os seguintes temas: a) Metais em África e as Transformações Químicas; b) Congadas em Goiás e suas implicações na extração de nióbio em Catalão-GO; c) Animais em África e o elemento ferro e; d) O uso de plantas em religiões de matriz Africana e suas contribuições fitoquímicas.

Nesse artigo serão analisados os dados obtidos da avaliação intitulada "Conhecimentos tradicionais de povos e comunidades de Matriz Africana". Os assuntos, as abordagens (conceitual e cultural) e os cursos de cada aluno/a estão sumarizados no Quadro 4.

O corpus total de análise foi formado pela transcrição de $3 \mathrm{~h} 05 \mathrm{~min}$ provenientes de gravações em áudio e vídeo dos discursos produzidos. Os dados obtidos foram agrupados por unidades de significação e analisados com elementos da técnica de Análise do Discurso (AD) de Bakhtin. ${ }^{64} \mathrm{~A}$ escolha desta técnica de análise de dados significou um empreendimento em tentar explicar e entender "como se constrói o sentido de um texto e como esse texto se articula com a história e a sociedade que o produziu" (p.13). ${ }^{64}$

Por sua vez, o discurso como objeto de análise é, ao mesmo tempo, linguístico, histórico e ideológico. Sua análise é movimento de compreensão destes dois aspectos. Nessa perspectiva, os SI de nossa pesquisa são interpretados como sujeitos essencialmente ideológicos e históricos, cuja "palavra está sempre carregada de um conteúdo ou de um sentido ideológico ou vivencial" (p.99). ${ }^{65}$

Quadro 3. Assunto, abordagem cultural e conceitual para alguns tópicos da disciplina

\begin{tabular}{|c|c|c|}
\hline Assunto & Abordagem cultural de matriz africana & Abordagem conceitual - conhecimento químico \\
\hline $\begin{array}{l}\text { A arqueologia da África e suas técnicas. } \\
\text { Processos de datação. }\end{array}$ & $\begin{array}{l}\text { Achados arqueológicos em África que comprovam } \\
\text { que o/a africano/a detinha conhecimentos antes da } \\
\text { chegada do europeu naquele continente. }\end{array}$ & $\begin{array}{l}\text { Técnicas analíticas usadas em arqueometria, objetivos da } \\
\text { pesquisa e da análise arqueométricas, técnicas de datação, } \\
\text { técnicas usadas na prospecção arqueológica, técnicas de } \\
\text { conservação. }\end{array}$ \\
\hline Reações dos elementos $\mathrm{Fe}$, $\mathrm{Cu}$ e Ni. & tes & Estabilidade de complexos em solução, efeito quelato. \\
\hline \multirow{2}{*}{$\begin{array}{l}\text { Propriedades Físico-químicas do azeite de } \\
\text { dendê }\end{array}$} & \multirow{2}{*}{$\begin{array}{l}\text { A importância do dendê na formação e manutenção } \\
\text { da cultura Afro-brasileira. }\end{array}$} & Conceitos de \\
\hline & & Síntese de biodendê \\
\hline $\begin{array}{l}\text { Produção de diamantes e metais nobres em } \\
\text { alguns países do continente Africano e suas } \\
\text { implicações nas guerras civis em África. }\end{array}$ & $\begin{array}{l}\text { Guerra civil em Angola pela extração ilegal de } \\
\text { diamantes comandada por empresas inglesas e } \\
\text { estadunidenses e Apartheid na África do Sul. }\end{array}$ & $\begin{array}{l}\text { Alotropia dos elementos C, S, P e O. A química do } \\
\text { Pd e da Pt e a produção de drogas anticancerígenas; a } \\
\text { produção de catalisadores automotivos para o controle } \\
\text { da qualidade do ar. }\end{array}$ \\
\hline
\end{tabular}


Quadro 4. Assunto, abordagem cultural e conceitual para alguns tópicos da disciplina

\begin{tabular}{|c|c|c|c|}
\hline Assunto & $\begin{array}{l}\text { Abordagem conceitual de } \\
\text { matriz Africana }\end{array}$ & $\begin{array}{l}\text { Abordagem Cultural - } \\
\text { conhecimento científico }\end{array}$ & Aluno(a) \\
\hline \multirow{4}{*}{$\begin{array}{l}\text { O uso de plantas em religiões de } \\
\text { matriz Africana e suas contribuições } \\
\text { fitoquímicas. }\end{array}$} & \multirow{4}{*}{$\begin{array}{l}\text { Funções químicas presentes nas estru- } \\
\text { turas dos princípios ativos das plantas } \\
\text { e as principais reações de cada função. }\end{array}$} & \multirow{4}{*}{$\begin{array}{l}\text { As plantas em rituais religiosos de } \\
\text { matriz Africana. }\end{array}$} & A2: Agronomia (mulher negra). \\
\hline & & & $\begin{array}{l}\text { A4: Licenciatura em Ciências Bioló- } \\
\text { gicas (homem branco). }\end{array}$ \\
\hline & & & $\begin{array}{l}\text { A10: Bacharelado em Comunicação } \\
\text { Social (homem negro). }\end{array}$ \\
\hline & & & $\begin{array}{l}\text { A11: Bacharelado em Bibliotecono- } \\
\text { mia (mulher negra). }\end{array}$ \\
\hline
\end{tabular}

\section{RESULTADOS E DISCUSSÃO}

A religiosidade de matriz Africana brasileira é atualmente uma ressignificação dos cultos praticados no continente Africano por diferentes grupos étnicos. Segundo Bastide apud Lemos, "as populações negras trazidas ao Brasil pertenciam a diferentes civilizações e provinham das mais variadas regiões Africanas. Suas religiões eram partes de estruturas familiares, organizadas socialmente ou ecologicamente a meios biogeográficos" (p.10). ${ }^{66}$ Todavia, com o tráfico negreiro, "sentiram-se obrigadas a decifrar um novo tipo de sociedade, baseada na família patriarcal, latifundiária e em regime de castas étnicas (sistemas tradicionais, hereditários ou sociais de estratificação, baseados em classificações como raça, cultura, ocupação profissional)" (p.4). ${ }^{66}$

Mais do que um choque entre culturas e tradições com a religião cristã houve também muitas acomodações e adaptações, além de negociações e conflitos, marca da resistência Africana no Brasil. Isso porque, no Brasil de extensões territoriais imensas e de interiores sem estruturas físicas e materiais soluções foram criadas para acomodar as necessidades recíprocas e a magia dos/as negros/as foi um substituto a medicina. ${ }^{67} \mathrm{E}$ nesse contexto, o conhecimento que o/a negro/a escravizado/a tinha sobre plantas e folhas no combate as suas doenças e males foi de importância considerável.

Nesse sentido, as plantas e as folhas foram incorporadas ao cotidiano das pessoas, povos e comunidades tradicionais de matriz Africana como remédios caseiros, em forma de chás para aliviar dores, reanimar o estado físico e incluindo a disposição para a vida. ${ }^{60}$ No extrato do Quadro 5 mostramos os discursos produzidos sobre o uso da arruda, da jurema, do alecrim, do algodoeiro e do juá-de-capote em religiões de matriz Africana. Este momento discursivo se deu sobre a constituição identitária brasileira a partir dos conhecimentos trazidos para o Brasil por Africanos/as escravizados/as. O extrato a seguir teve uma duração de 44 min e produziu 58 turnos de discurso (T) e, por motivo de espaço, passamos a apresentar a análise de trechos do extrato.

Inicialmente, nota-se em nossos resultados uma predominância dos discursos de A4 sobre os demais membros do grupo. Isso se justifica pelo fato do mesmo ser um aluno do curso de licenciatura em Ciências Biológicas que já leciona na educação básica e que trabalhou com Botânica em sua iniciação cientifica. Portanto, "ele já possui seu discurso, o discurso de outrem" (p.150), ${ }^{65}$ entendendo aqui como o discurso de outrem o discurso já estabelecido, de certa forma, a "atmosfera do já dito" pela Botânica, objeto de estudo da Biologia.

No turno 84, A4 se refere às duas plantas utilizadas nos rituais de terreiro: a arruda e a rosa branca. A arruda tem nome científico Ruta graveolens $L$, Rutaceace, e é uma planta associada ao Exu, o Orixá intermediário entre Orum e Ayé (correspondente ao céu e a terra, no catolicismo) fazendo referências a elementos como o fogo e o feminino. Utilizada em banho, sacudimentos na Umbanda e nos Candomblés de Angola com a função de afastar a má sorte, tem o seu uso proibido nos terreiros Jêje-Nagôs da Bahia e do Rio de Janeiro por ser considerado "um ewó da nação", (interdito) ${ }^{69}$ Apesar de "ser considerada tóxica e abortiva, possui propriedades terapêuticas que combatem a clorose, paralisias, nevralgias, flatulências e incontinências urinária" (p.103) ${ }^{69}$ Nas folhas da arruda "são encontrados princípios amargos, resinas, gomas, taninos, rutina, psoraleno, quercetina, alcalóides, ácidos orgânicos, alantoína, saponinas triterpênicas e mucilagem" (p.9). ${ }^{70}$ As estruturas químicas dos principais constituintes da arruda estão apresentadas na Figura 1.

A Figura 1a representa a quercetina, substância a que são atribuídas às propriedades analgésicas; a rutina, Figura 1b, facilita a absorção da vitamina $\mathrm{C}$ pelo organismo; o psoraleno, Figura 1c é usado no tratamento do vitiligo e da psoríase e; por fim, alantoína, Figura 1d, tem efeito cicatrizante e possui ação anti-irritante auxiliando o sistema de defesa da pele no processo de proliferação de novas células. ${ }^{70}$

A atividade química/biológica de uma planta “[...] não decorre de um só elemento químico presente, mas da ação sinérgica de todos os componentes presentes na planta podendo, porém, estarem mais concentrados em uma ou mais partes dela, como: na raiz, no caule, na casca, na folha, na flor, no fruto e na semente" (p.10), tal como descrito na Quadro 6 das utilidades da arruda e os constituintes químicos, tal como apresentado na Figura 2. ${ }^{71}$

A Química se interessa pela "relação estrutura-atividade" que compreende o estudo dos efeitos que a estrutura de um composto (ligante), tal como apresentado na Figura 3, pode causar durante sua interação com o receptor biológico e, consequentemente, racionalizar os principais fatores que governam esta interação. ${ }^{73}$

Essa interação receptor-ligante foi verificada nas enunciações de A3, turno 114, quando fala sobre a jurema: "você falou muito de jurema e ela não é usada só em defumação. Ela é alucinógena e produz uma substância psicoativa, também a mesma da Iouasca, e elas são usadas no sertão de Pernambuco, pelo menos eu conheço de lá, têm umas tradições que usam por seu efeito psicoativo" (grifos nossos).

Quando se considera os componentes químicos responsáveis pelas atividades biológicas contidas nas plantas utilizadas nos rituais das religiões de matriz Africana passíveis de verificação empírica, diz-se que essa planta possui um papel funcional. Além desse papel, o funcional, as plantas também desempenham um papel sacral que, de acordo com Camargo, é "de valor simbólico, subjetivamente construído no mito e legitimado no rito, capaz de impregnar as plantas de poderes curativos emanados de forças sobrenaturais, segundo ditam os sistemas de crença dos quais fazem parte o doente, o curador e seu grupo familiar e social” (p.10). ${ }^{71}$

O elemento interdiscursivo - família citada no discurso de A2, no Turno 94, uma mulher negra do curso de Agronomia - "quem tem parentes que moram em interior sabe, [...] o vô já fala, o tio já fala, vamos pegar umas folhas pra fazer um chá pra curar a gripe " anuncia o tecido social que compõe e caracteriza A2 e suas relações, pois quando falo se manifesta em meu discurso o que trago em mim. Ainda que o interdiscurso (para Bakhtin, um discurso dentro de outro discurso) 
Quadro 5. Extrato 1: Discursos sobre plantas utilizadas em religiões de matriz Africana

\begin{tabular}{|c|c|c|}
\hline Turno & Identificação & Discurso \\
\hline 84 & A4 & $\begin{array}{l}\text { Bom gente, queremos falar sobre o uso de plantas em religiões de matriz Africana. Nós buscamos muita coisa sobre } \\
\text { o tema, o aspecto social e científico e queremos falar do poder medicinal das plantas que elas usam. Para uma melhor } \\
\text { compreensão do uso das plantas dentro das religiões abordadas vamos primeiro falar brevemente sobre cada religião em } \\
\text { si para que possamos ter uma noção do que vamos trabalhar ao longo da aula e após isso vamos abordar questões religio- } \\
\text { sas, medicinais... Bem aqui nós observamos o uso da arruda e rosa branca para a preparação em um ritual lá no terreiro. }\end{array}$ \\
\hline 94 & A2 & $\begin{array}{l}\text { As plantas, como a gente pode observar, há muito tempo são utilizadas como aplicação medicinal. Lá na África, nos países } \\
\text { Africanos, eles utilizam tanto na forma de ritual mesmo, pra benzer, pra fazer um ritual pra Deus ou eles usam como } \\
\text { forma de curar alguma doença, pra fazer chá entre outras coisas. Essas plantas, antigamente, eram muito utilizadas em } \\
\text { todo o lugar. Quem tem parentes que moram no interior sabe que quando está com uma doença o vô já fala, o tio já fala, } \\
\text { vamos pegar umas folhas pra fazer um chá pra curar a gripe. }\end{array}$ \\
\hline 95 & A4 & Fitoterapia. \\
\hline 96 & A2 & $\begin{array}{l}\text { Então, essa Fitoterapia, ela advém da África, das religiões de matriz africana. Agora as pessoas estão usando muitos } \\
\text { remédios, mas agora tem muita gente preocupada com formas de vida saudável, estão pensando mais no lado verde da } \\
\text { vida, estão vindo, provavelmente, junto com essas religiões de matriz Africana. Então, é uma cosia que a gente tá vendo } \\
\text { muito presente na nossa sociedade. }\end{array}$ \\
\hline 98 & A 2 & $\begin{array}{l}\text { Aqui, a gente está vendo o uso de Jurema como bebida e fumo para defumação no ritual. Mestre Canindé acostado em } \\
\text { Pai Rivas durante rito no Centro de Cultura Viva das Tradições Afro-brasileiras. }\end{array}$ \\
\hline 108 & A4 & $\begin{array}{l}\text { [...] E vai se estendendo a outras religiões, igual a gente vê lá na lavagem da escada de Nosso Senhor do Bonfim } \\
\text { (Nosso Senhor do Bonfim se refere à representação de Jesus Cristo ascendendo aos céus). que eles realizam e vocês } \\
\text { podem observar as baianas lá do Candomblé lavando com ervas de manjericão, alecrim... Eles usam a lavanda } \\
\text { pra dar um perfume que elas vão limpar, para os católicos é uma coisa realizada com o Nosso Senhor do Bonfim } \\
\text { para as baianas já têm outra significação e elas estão comemorando um outro aspecto dentro da religião delas. } \\
\text { [...] E o alecrim de horta, a atividade são os caboclos, o uso das folhas no preparo de chá para tosse com leite e ovos de } \\
\text { galinha e também para banhos, preparação de cama de İyàwó e preparação de água (macerado) para lavagem de cabeça. }\end{array}$ \\
\hline 109 & A4 & $\begin{array}{l}\text { Aqui nós podemos observar o algodoeiro. Eu vi muita planta que eles usam e eu nem tinha noção que poderia ter um } \\
\text { poder espiritual pra eles. O algodoeiro, o uso das folhas nos rituais de iniciação e em banho, trata-se de uma folha muito } \\
\text { quente e poderosa. Ela é usada e a associação religiosa é a Oxalá e a Orumilá. }\end{array}$ \\
\hline 114 & A3 & $\begin{array}{l}\text { Você falou muito de jurema e ela não é usada só em defumação. Ela é alucinógena e produz uma substância psicoativa, } \\
\text { também a mesma da Iouasca, e elas são usadas no sertão de Pernambuco, pelo menos eu conheço de lá, têm umas tradições } \\
\text { que usam por seu efeito psicoativo. }\end{array}$ \\
\hline 118 & A4 & $\begin{array}{l}\text { [...] Eu fiz trabalho com os Calungas lá em Cavalcante com Etnobotânica que é uma área da Biologia dentro da Botânica. } \\
\text { Nós trabalhamos esse vínculo da religiosidade com a Ciência e tem uma vertente dupla. [...] o que a gente geralmente } \\
\text { trabalha, ah! Isso daqui é bom pra tirar inchaço. E o que a gente faz? Vai pro laboratório, faz um histoquímica dela (planta) } \\
\text { retira os extratos essenciais e vê o que tem ali na planta. Faz todo o trabalho mesmo pra ver se a planta realmente tem } \\
\text { poderes curativos. [...] a gente fez, publicou um artigo sobre o boldo, eles usam o boldo nos trabalhos. E aqui, todo mundo } \\
\text { já tomou chá de boldo pra curar uma ressaca alguma vez? E tem um detalhe, o boldo é amplo, mas o boldo verdadeiro } \\
\text { só vai ter o poder curativo, aquele da folha pequeninha que é o boldo chileno. O boldo baiano não tem poder curativo e } \\
\text { esses boldos achados em beira de rio também não têm. }\end{array}$ \\
\hline
\end{tabular}

de A2 seja um discurso que celebre as figuras masculinas tio e avô, nota-se a referência a ancestralidade, ${ }^{49}$ um dos valores civilizatórios Africanos, pois A2 atribui ao conhecimento popular vindo de África a aplicação medicinal que algumas plantas utilizadas em religiões de matriz Africana possuem "as plantas, como a gente pode observar, há muito tempo são utilizadas como aplicação medicinal, lá na África, nos países Africanos".

No Egito, um país do continente Africano, as plantas eram utilizadas em rituais religiosos, para curar doenças, embalsamar corpos, em preparações aromáticas, antissépticas, cosméticas, purgativas, etc. ${ }^{74}$ As plantas que são utilizadas em religiões dos povos e comunidades de matriz Africana e que possuem algum princípio ativo ou substância capaz de prevenir, aliviar ou curar uma doença são também plantas medicinais. ${ }^{75}$ Esse termo foi "oficialmente" reconhecido durante a $31^{\text {a }}$ Assembleia da Organização Mundial de Saúde (OMS), sendo então definido como "aquela que administrada ao homem ou animais, por qualquer via ou sob qualquer forma, exerce alguma espécie de ação farmacológica" (p.71). ${ }^{75}$ 
A)<smiles>O=c1c(O)c(-c2ccc(O)c(O)c2)oc2cc(O)cc(O)c12</smiles>

C)<smiles>[R]c1c2ccoc2cc2oc(=O)ccc12</smiles>

B)<smiles>COC(O)C(C)OC1C2OC(OC3C=C(O)C=C(O)C3C2=O)C1O</smiles>

Figura 1. Estrutura química dos principais constituintes químicos presentes nas folhas de arruda: (A) quercetina $\left(C_{15} H_{10} O_{7}\right) ;(B)$ rutina $\left(C_{27} H_{30} O_{16}\right) ;(C)$ psoraleno $\left(\mathrm{C}_{11} \mathrm{H}_{6} \mathrm{O}_{3}\right)$ e; (D) alantoína $\left(\mathrm{C}_{4} \mathrm{H}_{6} \mathrm{~N}_{4} \mathrm{O}_{3}\right)$

Quadro 6. As utilidades da arruda: Ruta graveolens Linneau (RUTACEAE)

\begin{tabular}{|c|l|l|}
\hline Partes utilizadas & \multicolumn{1}{|c|}{ Propriedades Medicinais } & \multicolumn{1}{c|}{ Utilização Religiosa } \\
\hline Folhas e flores. & $\begin{array}{l}\text { Anti-helmintica, anti-hemorrágica, anticoagulante, } \\
\text { anticonvulsiva, antireumática, digestiva, emena- } \\
\text { goga, fortificante dos nervos, febrífuga. }\end{array}$ & $\begin{array}{l}\text { No meio popular é considerada planta protetora contra mau olhado e } \\
\text { quebranto. Dizem que basta tê-la em casa para afastar maus elementos, } \\
\text { usa-se ainda em defumador para "descarregar" ambientes. }\end{array}$ \\
\hline
\end{tabular}

Constituintes Químicos: Furanocumarinas: (bergapteno xantotoxina, psoraleno) (Figura 2); Alcalóides: graveolinina (Figura 3); Outros: ácido anísico; Flavonóides: rutina; Taninos: ácido gálico.

*Fonte. ${ }^{72}$<smiles>[R2]c1c2ccoc2c([R2])c2oc(=O)ccc12</smiles>

$$
\begin{aligned}
& \mathrm{R}_{1}=\mathrm{R}_{2}=\mathrm{H} \text { (psoraleno) } \\
& \mathrm{R}_{1}=-\mathrm{OCH}_{3}, \mathrm{R}_{2}=\mathrm{H} \text { (bergapteno) } \\
& \mathrm{R}_{1}=\mathrm{H}, \mathrm{R}_{2}=-\mathrm{OCH}_{3} \text { (xantotonina) }
\end{aligned}
$$

Figura 2. Estrutura química do bergapteno, xantotoxina e psoraleno $\left(\mathrm{C}_{11} \mathrm{H}_{6} \mathrm{O}_{3}\right)$<smiles>COc1cc(-c2ccc3c(c2)OCO3)nc2ccccc12</smiles>

Figura 3. Estrutura química da graveolinina $\left(\mathrm{C}_{17} \mathrm{H}_{13} \mathrm{NO}_{3}\right)$

Nessa ocasião, a OMS criou o Programa de Medicina Tradicional que recomendou aos estados-membros o desenvolvimento de políticas públicas para facilitar a integração da medicina tradicional e da medicina complementar alternativa nos sistemas nacionais de atenção à saúde, por considerar que "grande parte da população dos países em desenvolvimento depende da medicina tradicional para sua atenção primária, tendo em vista que $80 \%$ desta população utilizam práticas tradicionais nos seus cuidados básicos de saúde e $85 \%$ destes utilizam plantas ou preparações desta" (p.11). ${ }^{76}$

Tal prática correspondia na época, aproximadamente, 5 bilhões de pessoas e ainda $85 \%$ dessa medicina tradicional envolvia o uso de extratos vegetais. ${ }^{77}$ Entendemos que o conhecimento científico não é saber tradicional, mas com ele se comunica. Nossos resultados mostram como é possível trazer esta temática para a aula de Química, pois em consonância com Botelho, pode-se dizer que "[...] o ensino e a aprendizagem que ocorrem nas salas de aula representam uma das maneiras de construir significados, reforçar e conformar interesses sociais, formas de poder, de experiência que têm sempre um significado cultural e político" (p.166). ${ }^{78}$

Com o intuito de manter, minimamente, a sua cultura o/a negro escravizado/a adotou uma postura política em relação à religião praticada na sua terra mãe. Esse/a passou a associar os seus Orixás e as suas divindades aos santos da Igreja do/a seu/a colonizador/a. No texto intitulado "A Umbanda em julgamento" Alfredo d'Alcântara afirma: "não era a óstia uma semelhança da pedra de Xangô? Jesus Cristo morava na óstia, como Xangô morava na pedra de raio; apenas esta não podia ser engolida. O rosário de Nossa Senhora era bem igual à guia de contas vegetais de Yemanjá e ao Opelê-Ifá de que serviam os Babalaôs" (p.67). ${ }^{79}$

Essa prática deu origem ao sincretismo religioso, prática muito comum nas religiões cultuadas por povos e comunidades tradicionais de matriz Africana. Esse sincretismo é evidenciado quando estes povos e comunidades fazem uso da jurema em seus cultos. De nome científico Acacia jurema Mart, Leguminosae-mimosoideae, a jurema tem o seu uso associado aos Orixás do Candomblé, Ossaim Orixá “das folhas e da saúde, que é considerado o curandeiro, porque conhece o segredo das plantas que curam" (p.7) ${ }^{80}$ e Oxossi, divindade da caça 
Quadro 7. As utilidades do alecrim: Rosmarinus officinalis L. Labiatae (LAMIACEAE)

\begin{tabular}{|c|l|l|}
\hline Partes utilizadas & \multicolumn{1}{|c|}{ Propriedades Medicinais } & \multicolumn{1}{|c|}{ Utilização Religiosa } \\
\hline Talo, folhas, flores e óleo essencial. & $\begin{array}{l}\text { Antimicótico, antifúngico, anti-helmíntico, antiséptico, antiinfla- } \\
\text { matório, analgésico, bactericida, colagogo, cicatrizante, colerético, } \\
\text { diurético, estimulante do sistema nervoso, estimulante do couro } \\
\text { cabeludo, emenagoga, expectorante, fungistático, hidrocolerético, } \\
\text { hepatoprotetor, tônico, rubefaciente. }\end{array}$ & $\begin{array}{l}\text { Ele é } \\
\text { com outras plantas, indicado contra mau-olhado. } \\
\text { Em Portugal, usava-se para livrar criança de } \\
\text { quebranto. }\end{array}$ \\
\hline Constituintes Químicos: Tanino: ácido gálico (Figura 4); Flavonóide: apigenina (Figura 5); Outros: Diterpenóides: ácidos ursólico; Óleos essenciais: mirceno. \\
\hline
\end{tabular}

Fonte $^{72}$

que vive nas florestas e a Caboclos (entidades da Umbanda), fazendo referências a elementos como a terra e o masculino. A jurema era utilizada ainda pelos indígenas brasileiros que a utilizavam "segundo suas crenças, para excitar os sentidos, provocando sonhos, estados de êxtase e de encantamento nas pessoas. A casca dessa árvore é adstringente, febrífuga e narcótica, aconselhada contra úlceras, cancros, flegmões e erisipela. Suas sementes, segundo alguns manuais de fitoterapia, são tóxicas" (p.398). ${ }^{69}$

O sincretismo presente em algumas religiões de matriz Africana é verificado também nos discursos de A4, no turno 108, quando em suas enunciações quanto ao uso das ervas na lavagem das escadas da Igreja de Nosso Senhor Bonfim, Santo da Igreja Católica, pelas baianas do Candomblé. Segundo A4, "para os católicos é uma "coisa" realizada com o Santo Nosso Senhor do Bonfim para as baianas já têm outra significação e elas estão comemorando outro aspecto dentro da religião delas". A4 cita ainda a utilização do alecrim, umas das ervas utilizadas na lavagem das escadas da Igreja de Nosso Senhor Bonfim, nas atividades dos caboclos (Umbanda) através do“[...] uso das folhas no preparo de chá para tosse com leite e ovos de galinha e também para banhos, preparação de cama de İyàwó e preparação de água (macerado) para lavagem de cabeça".

O alecrim, de nome científico Rosmarinus officinalis L, Labiatae, associado a Oxalá, divindade do céu e da procriação, o pai de todos os Orixás, é utilizado em banhos e em defumações. Medicinalmente como chá, pode ser usado no caso de má digestão. Se conservada em álcool pode combater o reumatismo e a encefalia por meio de fricções locais. ${ }^{75}$ Seu "óleo volátil é antibacteriano, enquanto que a infusão da planta é usada para o tratamento sintomático de problemas digestivos, devido as suas propriedades antiespasmódicas e coleréticas, dada a presença de compostos fenólicos (p. 11)", ${ }^{81}$ tal como descrito no Quadro 7 das utilidades do alecrim e os constituintes químicos, tal como apresentado na Figura 4 e 5.<smiles>O=C(O)c1cc(O)c(O)c(O)c1</smiles>

Figura 4. Estrutura química do ácido gálico $\left(\mathrm{C}_{17} \mathrm{H}_{6} \mathrm{O}_{5}\right)$

No turno 109, A4 se surpreende mesmo sendo um estudante do curso de Ciências Biológicas e que tenha feito a sua iniciação científica em Botânica: "Eu vi muitas plantas que eles usam e eu não tinha nem noção que poderia ter um poder espiritual pra eles". Essa invisibilidade no uso das plantas pelos povos e comunidades de matriz Africana, notadas por A4, é reflexo da pequena quantidade de pesquisa sobre esses povos. Até o ano de 2015, quando da publicação do I Plano Nacional de Desenvolvimento Sustentável dos Povos e Comunidades Tradicionais de Matriz Africana, "apenas sete levantamentos haviam sido realizados por instituições públicas, privadas e universidades que<smiles>Cc1cc(C)c2c(=O)cc(-c3ccc(O)cc3)oc2c1</smiles>

Figura 5. Estrutura química da apigenina $\left(\mathrm{C}_{15} \mathrm{H}_{10} \mathrm{O}_{5}\right)$

buscaram cadastrar, inventariar ou mapear territórios tradicionais de matriz africana" (p.18). ${ }^{50}$

Também no turno 109, A4 se refere ao uso do algodoeiro, nome científico Gossypium barbadense L, Malvaceae, associada ao Oxalá e a Orumilá, divindades do conhecimento e da sabedoria e faz referências a elementos como a ar e o feminino. De grande prestígio entre os Jêje-Nagôs é utilizado no combate a enfermidades próprias da mulher, tais como: desordens menstruais, hemorragias pós-parto, inflamações e dores no útero, retenção da placenta e para provocar contrações uterinas. Segundo Barros, o algodoeiro é usado também nos "casos em que as senhoras que amamentam não têm leite ou este é escasso, quando ele promove e faz aumentar a secreção das glândulas mamárias" (p.204). ${ }^{69}$

No entanto, o algodoeiro que é utilizado no tratamento de vários "problemas da mulher", ${ }^{69}$ não é capaz de aliviar a dor da vulnerabilidade social imposta pela sociedade brasileira às mulheres em geral e, em especial, à mulher negra moradora das comunidades tradicionais de matriz Africana. Os resultados publicados na pesquisa Mapeando o Axé - Pesquisa Socioeconômica e Cultural das Comunidades Tradicionais de Terreiro $(2010 / 2011)^{50}$ corroboram essa assertiva. Das 7.582 casas de povos e comunidades tradicionais de matriz Africana pesquisadas, $72 \%$ das lideranças se autodeclararam negras e 55,6\% são mulheres. Mesmo com esse protagonismo as mulheres negras vivenciam o mais alto grau de vulnerabilidade social.

O Quadro 8 apresenta os dados da Pesquisa Nacional por Amostra de Domicílios (PNAD) do IBGE de 2015..$^{50}$ Entre as mulheres, que representam mais da metade da população brasileira $(51,5 \%)$, as negras são metade, ou seja, representavam em 2015 52,7 milhões de brasileiras. Segundo essa pesquisa o rendimento médio de uma mulher negra é o menor do Brasil. Os dados referentes à situação de pobreza, por sua vez, indicam que $7,4 \%$ das mulheres negras brasileiras vivem em situação de extrema pobreza.

Esses dados significam, de fato, que o rendimento médio de um homem branco é 2,5 vezes maior do que o rendimento de uma mulher negra. Indicam, também, que o número de mulheres negras em situação de pobreza extrema é 2,5 vezes maior que o número de homens brancos na mesma situação e, ainda, que o número de homens brancos em situação de pobreza é 2,4 vezes menor que o número de mulheres negras.

A possibilidade de ressaltar a importância dos conhecimentos 
Quadro 8. Dados Pesquisa Nacional por Amostra de Domicílios (PNAD) do IBGE (2015)

\begin{tabular}{|l|c|c|}
\hline Indicativo & Mulher Negra & Homem Branco \\
\hline Rendimento médio & $\mathrm{R} \$ 655,70$ & $\mathrm{R} \$ 1.675,10$ \\
\hline Situação de pobreza & $13,4 \%$ & $5,6 \%$ \\
\hline Situação de extrema pobreza & $7,4 \%$ & $2,9 \%$ \\
\hline
\end{tabular}

Fonte: Adaptado de Plano Nacional de Desenvolvimento Sustentável dos Povos e Comunidades Tradicionais de Matriz Africana. ${ }^{50}$

de comunidades tradicionais Afro-brasileiras sobre ervas e plantas medicinais em aula de Química representa uma alternativa de combate às violências sofridas por estas comunidades. Pois, conhecimento científico e saber tradicional são formas de procurar entender e agir sobre o mundo, formas de produzir cultura e, também, obras inacabadas e em constante negociação entre as respectivas comunidades científica e tradicional. Estabelecer o diálogo entre essas diferentes formas de se relacionar com o mundo é necessário para romper com o epistemícidio que atinge nossas salas de aula.

\section{ALGUMAS CONSIDERAÇÕES}

Nossos resultados mostram que foi possível inserir a lei 10.639/03 no ensino de Química. A IP desenvolvida se mostrou como uma alternativa para discutir em sala de aula de Química as contribuições dos povos e comunidades de matriz Africana (os saberes tradicionais) e suas relações com o conhecimento científico: contribuições para a produção de fitoterápicos, suas implicações físico-químicas e suas formas de ser transposta aos estudantes do ensino superior.

Utilizar a natureza em fins terapêuticos é prática que remonta a organização da humanidade. Este e todos os outros saberes sociais são construções humanas que passam pela transformação da matéria (objeto de estudo da Química) e que são difundidos por gerações. Nossos resultados apontam que a escola também é local de manutenção da difusão desses conhecimentos.

Observar os valores civilizatórios dos que foram trazidos e que aqui se mantêm resistentes às violências e violações de direitos passa por modificar nossos currículos de olhares brancos e europeus.

\section{AGRADECIMENTOS}

O presente trabalho foi realizado com apoio da Coordenação de Aperfeiçoamento de Pessoal de Nível Superior - Brasil (CAPES) Código de Financiamento 001.

Os/as autores/as agradecem ao Centro Cultural Ilê Orê por trazer axé a nosso Ori, ao fotógrafo Douglas Luzz pelo registro do sagrado, ao CNPq e a FAPEG pelos fomentos concedidos.

\section{REFERÊNCIAS}

1. Este artigo é uma versão ampliada e revisada do texto apresentado pelos/ as autores/as na IX edição do Congresso Brasileiro de Pesquisadores/as Negros/as, 2017.

2. Marques Junior, J. S.; O Social em Questão - Ano XX. 2017, 37, 37.

3. http://www.planalto.gov.br/ccivil_03/LEIS/2003/L10.639.htm, acessada em março de 2019.

4. http://portal.mec.gov.br/seesp/arquivos/pdf/lei9394_ldbn1.pdf, acessado em março de 2019.

5. http://portal.mec.gov.br/dmdocuments/cnecp_003.pdf, acessado em março de 2019.

6. http://etnicoracial.mec.gov.br/images/pdf/diretrizes_curric_educ_ etnicoraciais.pdf, acessado em março de 2019.
7. http://portal.mec.gov.br/dmdocuments/orientacoes_etnicoraciais.pdf, acessado em março de 2019.

8. Verrangia, D.; Revista África e Africanidades 2010, 2, 14.

9. http://portal.mec.gov.br/cne/arquivos/pdf/res012004.pdf, acessado em março de 2019.

10. Francisco Júnior, W. E.; Quim. Nova Esc. 2007, 26, 10.

11. Francisco Júnior, W. E.; Ciência \& Educação 2008, 14, 397.

12. Benite, A. M. C.; Souza, E. P. L.; Alvino, A. C. B.; Anais do VIII Encontro Nacional de Pesquisa em Educação em Ciências e I Congreso Iberoamericano de Investigaciónen Enseñanza de las Ciencias, Rio de Janeiro, Brasil, 2011.

13. Souza, E. P. L; Alvino, A. C. B.; Santos. M. A; Benite, A. M. C.; Anais do XVI Encontro Nacional de Ensino de Química (XVI ENEQ) e X Encontro de Educação Química da Bahia (X EDUQUI), Salvador, Brasil, 2012.

14. Souza, E. P. L.; Dissertação de Mestrado, Universidade Federal de Goiás, Brasil, 2014.

15. Brito, M. C. L; Lopes, E. T.; Anais do XVIII Encontro Nacional de Ensino de Química, Florianópolis, Brasil, 2016.

16. Brito, M. C. D. L.; Dissertação de Mestrado, Universidade Federal de Sergipe, Brasil, 2017.

17. Alvino, A. C. B.; Silva, J. P.; Benite, A. M. C.; Anais do XVII Encontro Nacional de Ensino de Química, Ouro Preto, Brasil, 2014.

18. Pinheiro, J. S., Silva, R. M. G.; Anais do XIV Encontro Nacional de Ensino de Química, Curitiba, Brasil, 2008.

19. Pinheiro, J. S.; Dissertação de Mestrado, Universidade Federal de Uberlândia, Brasil, 2009.

20. Santos, E. S.; Rodrigues Filho, G.; Amauro, N. Q.; Atas do IX Encontro Nacional de Pesquisa em Educação em Ciências, Águas de Lindóia, Brasil, 2013.

21. Pinheiro, J. S.; Henrique, H. C. R.; Santos, E. S.; Anais do XV Encontro Nacional de Ensino de Química, Brasília, Brasil, 2010.

22. Dionysio, R. B.; Amorim, G. C.; Oliveira, R. D. V. L.; Revista Práxis 2015, 14, 63 .

23. Francisco Júnior, W. E.; Quim. Nova Esc. 2017, 40, 79.

24. Francisco Júnior, W. E.; Silva, E. M. dos S.; Yamashita, M.; Atas do IX Encontro Nacional de Pesquisa em Educação em Ciências, Águas de Lindóia, Brasil, 2013.

25. Santos, R. G.; Siemsen, G. H.; Silva, C. S.; Atas do IX Encontro Nacional de Pesquisa em Educação em Ciências, Águas de Lindóia, Brasil, 2015.

26. Moreira, P. F. S. D.; Amauro, N. Q.; Rodrigues Filho, G.; Atas do IX Encontro Nacional de Pesquisa em Educação em Ciências, Águas de Lindóia, Brasil, 2013.

27. Silva, L. G.; Pinheiro, B. C. S.; Revista da ABPN 2017, 9, 191.

28. Benite, A. M. C.; Bastos, M. A.; Vargas, R. N.; Fernandes, F. S.; Faustino, G. A. A.; Educação em Revista 2018, 34, e193098.

29. Vargas, R. N.; Faustino, G. A. A.; Fernandes, F. S.; Benite, A. M. C.; Ser Social 2018, 20, 348.

30. Silva, L. H.; Pinheiro, B. C. S.; Revista Debates em Ensino de Química. 2017, 4, 5 .

31. Santos, A. B.; Moura, V. C. T.; Moreira, P. F. S. D.; Anais do XVIII Encontro Nacional de Ensino de Química, Florianópolis, Brasil, 2016.

32. Bastos, M. A.; Amauro, N. Q; Benite, A. M. C.; Revista da ABPN 2017, 9, 312 .

33. Bastos, M. A; A. M. C.; Revista da ABPN 2017, 9, 64

34. Benite, A. M. C.; Bastos, M. A.; Camargo, M. J. R.; Vargas, R. N.; Lima, G, L. M.; Benite, C. R. M.; Quim. Nova Esc. 2017, 2, 131.

35. Benite, A. M. C.; Silva, J. P.; Alvino, A. C.; Educação em Foco 2017, 21,735 .

36. Silva, J. P.; Benite, A. M. C.; Revista da ABPN 2017, 9, 273.

37. Lima, G. L. M.; Alvino, A. C. B.; Moreira, M. B.; Silva, J. P.; Moura, A. R.; Silva, A. G.; Faustino, G. A. A.; Bastos, M. A.; Benite, A. M. C.; 
Anais do XVIII Encontro Nacional de Ensino de Química, Florianópolis, Brasil, 2016.

38. Santos, V. L. L.; Benite, A. M. C.; Revista da ABPN 2018, 10, 125.

39. Silva, J. P.; Faustino, G. A. A.; Alvino, A. C. B.; Bastos, M. A.; Moura, A. R.; Lima, G. L. M.; Silva, A. G.; Fernanda, F. S.; Benite, A. M. C.; Anais do XVIII Encontro Nacional de Ensino de Química, Florianópolis, Brasil, 2016.

40. Heidelmann, S. P.; Silva, J. F. M. S; Pinho, G.; Anais do XVIII Encontro Nacional de Ensino de Química, Florianópolis, Brasil, 2016.

41. Sutherland, E.; Coltan, the Congo and Your Cell Phone (April 11, 2011), disponível em http://dx.doi.org/10.2139/ssrn.1752822, acessado em março de 2019.

42. Benite, A. M. C.; Silva, J. P.; Roteiros temáticos da diáspora: caminhos para o enfrentamento ao racismo no Brasil; Kominek, A. M. V., Vanali, A. C., eds.; Fi: Porto Alegre, 2018, cap. 8.

43. Moreira, P. F. S. D.; Rodrigues Filho, G.; Fusconi, R.; Jacobucci, D. F. C.; Quim. Nova Esc. 2011, 22, 85.

44. Silva, J. S.; Alvino, A, C. B.; Santos, M. A.; Santos, V. L.; Benite, A. M C.; Quim. Nova Esc. 2017, 39, 19.

45. https://ensaiosenotas.files.wordpress.com/2017/04/ocatere-povostradicionais.pdf, acessada em março de 2019.

46. http://www.planalto.gov.br/ccivil_03/_ato2007-2010/2007/decreto/ d6040.htm, acessada em março de 2019.

47. Martins, A. R.; Junior, W. R. S. Revista do Instituto de Estudos Brasileiros (RIEB) 2017, 68, 32

48. https://www.geledes.org.br/liderancas-de-matriz-africana-divulgamtexto-orientador-em-plenaria-da-iii-conapir/, acessada em março de 2019.

49. http://www.acordacultura.org.br/oprojeto, acessado em março de 2019.

50. https://www.mdh.gov.br/biblioteca/igualdade-racial/plano-nacional-dedesenvolvimento-sustentavel-dos-povos-e-comunidades-tradicionais-dematriz-africana/view, acessada em Março de 2019.

51. http://www.planalto.gov.br/ccivil_03/_ato2015-2018/2016/decreto/ D8750.htm, acessada em Março de 2019.

52. Ferretti, M.; Repensnado o Sincretismo: Estudo sobre a Casa das Minas. Editora Universidade de São Paulo: São Paulo, 1995.

53. Costa Neto, A. G.; Dissertação de Mestrado, Universidade de Brasília, Brasília, 2010.

54. http://www.seppir.gov.br/central-de-conteudos/noticias/2016/pretos-epardos-sao-maiores-vitimas-das-denuncias-de-violacoes-de-direitoshumanos, acessada em março de 2019.

55. Werneck, J.; Iraci, N. A situação dos direitos humanos das mulheres negras no Brasil: Violências e Violações, Geledés e Criola: São Paulo, 2016.

56. Novaes, B. A.; Anais do Congresso ANPTECRE, Curitiba, Brasil, 2015.

57. https://www.todamateria.com.br/umbanda/, acessada em abril de 2018.
58. Nascimeto, A. A. S.; Revista Brasileira de Sociologia da Emoção 2010, $8,27$.

59. https://www.todamateria.com.br/candomble/, acessada em março de 2019.

60. Siqueira, M. L.; Agô, Agô, Lonan, Mazza Edições: Belo Horizonte, 1998.

61. Brandão, C. R (Org); Pesquisa Participante. São Paulo: Brasiliense, 1984.

62. Demo, P.; Pesquisa participante: saber pensar e intervir juntos, Plano: Brasília, 2004.

63. Gomes, N. L.; Currículo sem Fronteiras 2012, 1, 98.

64. Gregolin, M. R. F. V.; Alfa 1995, 39, 13.

65. Bakhtin, M. M.; Marxismo e Filosofia da Linguagem, $12^{\text {a }}$ ed., Hucitec: São Paulo, 2006.

66. Lemos, M. J.; Monografia de Licenciatura Plena em História, Faculdade do Médio Parnaíba, Teresina, 2014.

67. Bittar, E. C. B.; Seqüência: Estudos Jurídicos e Políticos 2011, 1, 311.

68. Rocha, Y. T.; Religiões e Ciências 2011, 3, 1.

69. Barros, J. F. P.; Napoleão, E.; Ewé Òrìsà: Uso Litúrgico e Terapêutico dos vegetais nas casas de Candomblé Jêje-Nagô, $7^{\text {th }}$ ed., Bertrand Brasil: Rio de Janeiro, 2015.

70. Orlanda, J. F. F.; Tese de Doutorado, Universidade Federal da Paraíba, João Pessoa, 2011.

71. Camargo, M. T. L. A.; Revista do Núcleo de Estudos de Religião e Sociedade 2014, 26, 1.

72. Bernardes, P. S.; Ferreira, D. T.; Resumos da 2 a Seminário de Educação e Diversidade Étnico-Racial Discutindo as Diferenças, Londrina, 2007.

73. Arroio, A; Honorio, K. M.; Silva, Albérico B. F.; Quim. Nova 2010, 33, 694.

74. Barsa, Nova Enciclopédia. V. 9, Encyclopedia Britannica do Brasil Publicações: São Paulo, 1998.

75. David, J. P.; David, J. M.; Planta Medicinais, $6^{\text {th }}$ ed., Rio de Janeiro: Guanabara Koogan, 2002

76. http://bvsms.saude.gov.br/bvs/publicacoes/politica_nacional_ fitoterapicos.pdf, acessada em Março de 2019.

77. Farnsworth, N. R. Em Screening plants for new medicines; Wilson, E. O., ed.; National Academy Press: Washington DC, 1988.

78. Santomé, J. T. Em As culturas negadas e silenciadas no currículo, $6^{\text {th }}$ ed.; Silva, T. T., org.; Petrópolis: Vozes, 1995.

79. d'Alcântara, A.; A Umbanda em julgamento, Rio de Janeiro: 1949

80. Botelho, P. F.; Revista de Educação, Gestão e Sociedade 2011, 4, 1.

81. Sousa, M. S.; Lima, M. F.; Plantas sagradas nas religiões afrobrasileiras: correlações do seu terapêutico e a fitoterapia, UFG: Goiânia, s/d, artigo digitado, 2011, pp. 1-20, disponível em https:// studylibpt.com/doc/3193386/plantas-sagradas-nas-religi\%C3\%B5esafro-brasileiras, acessada em março de 2019. 